\title{
ETHNICITY, ASSIMILATION AND THE ISRAELITE SETTLEMENT
}

\author{
Pekka Pitkänen
}

\begin{abstract}
Summary
In this article, we look into the possibility of assimilation of Canaanites $^{1}$ into a group of Israelites whose origins lie in Egypt. We examine the topic from a comparative perspective of studies of ethnicity. First, we make a review of the current status of the scholarship about the origins of Israel. We then review how studies of ethnicity have been applied to Old Testament studies. After this, we look at definitions and basic features of ethnicity from the standpoint of ethnic studies. We then apply these insights to determine basic features of ethnicity and ethnic boundaries in early Israel. Subsequently, we look into evidence which suggests that assimilation from local peoples to an Exodus group may well have taken place in early Israel. ${ }^{2}$
\end{abstract}

\section{The Origins of Israel in Past Scholarship}

The origins of Israel have presented a problem for Old Testament scholarship. Besides criticisms laid on the biblical text since the $19^{\text {th }}$ century, ever since archaeological results from the ancient Levant started to accumulate in the $20^{\text {th }}$ century, the results from archaeological excavations were compared with the biblical data. In broad sweep, three different models to account for the origins of Israel emerged.

First, there were those who wished to affirm the basic historicity of the biblical text, even if the date of the conquest was to be lowered to the $13^{\text {th }}$ century and the time of the Late Bronze-Early Iron Age transition instead of the $15^{\text {th }}$ century as suggested by the biblical

1 Term used here and in most parts of the article in a broad geographical sense.

2 This paper was originally given as the Tyndale Old Testament Lecture 2004. 
chronology. The most illustrious proponent of this view was William Albright, and his work was continued by his disciples, the most notable of whom was John Bright. ${ }^{3}$ However, there were, and still are, a number of problems with this model. ${ }^{4}$ First of all, besides problems with identifying any external corroboration for the Israelite stay in Egypt and for the Exodus and the wilderness wanderings, ${ }^{5}$ there are problems with fitting the biblical evidence with archaeological evidence from Transjordania. ${ }^{6}$ However, there are also major problems with the Cisjordan. Perhaps the biggest problems relate to the stories about Jericho and Ai (Josh. 6; 7-8). While the original excavations by Garstang affirmed the biblical story about the conquest, Kenyon's new excavations in the 1950s gave a different story. According to Kenyon, ${ }^{7}$ the city was destroyed at the end of Middle Bronze Age, much too early for the Israelite conquest. What is more, according to Kenyon, ${ }^{8}$ the site was largely abandoned during Late Bronze Age, and was occupied only late in the Iron Age. Therefore, it appears that there was no town for the Israelites to conquer, contrary to the biblical account in Joshua. Also, there seems to have been no occupation in Ai during the time of the Israelite conquest. ${ }^{9}$ In addition to the problems relating to Jericho and $\mathrm{Ai}$, a further major problem for the conquest theory is that no occupation has been found from such sites as Arad and Gibeon during Late Bronze Age. ${ }^{10}$

3 For a succinct summary, including bibliographical references to Albright and Bright, see W. G. Dever, Who Were the Early Israelites and Where Did They Come From?(Grand Rapids, Michigan: Eerdmans, 2003): 41-49.

4 See Dever, Early Israelites: 44-45.

5 See Dever, Early Israelites: 7-21, but see J. K. Hoffmeier, Israel in Egypt: The Evidence for the Authenticity of the Exodus Tradition (Oxford: University Press, 1997) for positive evidence for the sojourn in Egypt and for the Exodus.

6 For a summary of the state of affairs, see Dever, Early Israelites: 26-35.

7 K. Kenyon, 'Jericho' in The New Encyclopedia of Archaeological Excavations in the Holy Land, ed. E. Stern (Jerusalem: Israel Exploration Society \& Carta, 1993): 679-80.

8 Jericho: 680.

9 Dever, Early Israelites: 47; cf. J. Callaway, 'Ai' in The New Encyclopedia of Archaeological Excavations in the Holy Land, ed. E. Stern (Jerusalem: Israel Exploration Society \& Carta, 1993): 43-45.

10 See Dever, Early Israelites: 29-30, 48-49; cf. Y. Aharoni, 'Arad' in The New Encyclopedia of Archaeological Excavations in the Holy Land, ed. E. Stern (Jerusalem: Israel Exploration Society \& Carta, 1993): 82-87; J. B. Pritchard, 'Gibeon' in Encyclopedia, ed. E. Stern: 511-14). Note however the recent works of I. Provan, V. P. Long, and T. Longman III, A Biblical History of Israel (Louisville: Westminster John Knox, 2003) and K. A. Kitchen, On the Reliability of the Old Testament (Grand Rapids: Eerdmans, 2003) which seek to find positive solutions to these problems. 
Another model is the 'peaceful infiltration' model which originated from the German scholars Albrecht Alt and Martin Noth in the early $20^{\text {th }}$ century. According to this model, the Israelites were nomads who immigrated and settled the land over a long period of time. However, besides not being consistent with the biblical accounts, the model has been criticised for its lack of understanding of nomadic life in the region. ${ }^{11}$ In addition, the model assumes that the Israelites were immigrants from outside, a premise that has increasingly been challenged (see below).

The third model was initiated by Mendenhall and Gottwald. According to them, ${ }^{12}$ the Israelites had their origins with an underclass which revolted against the Canaanite upper class, withdrew to the highlands and settled there with the resulting formation of a society which was to become Israel. ${ }^{13}$ This model has been criticised for its Marxist socio-political analysis. ${ }^{14}$ However, the main legacy of the 'peasants revolt' model is that it drew attention to the possibility of indigenous origins of the Israelites. In fact, though ditching the 'peasants revolt' model, subsequent scholarship has essentially sought to explain the birth of Israel as an indigenous development.

A major attempt to understand the birth of Israel based on indigenous origins was made by Coote and Whitelam. ${ }^{15}$ They sought to explain the Late Bronze-Early Iron Age transition against the backdrop of cyclical variation in the ancient Levant over millennia. Coote and Whitelam suggested climate change and collapse of trade structures as the driving force behind the changes which led to the collapse of the Late Bronze culture and the birth of the Iron Age culture from which

These works were unavailable to me at the time of writing this article. Also, it is worth mentioning that the question of the date for the supposed exodus and conquest has surfaced at times (most notably J. J. Bimson, Redating Exodus and the Conquest; JSOTSup, 5; Sheffield: Almond, 1981).

11 See Dever, Early Israelites: 51-52.

12 While different in details, the basic principles of the models proposed by Mendenhall and Gottwald are similar.

13 See Dever, Early Israelites: 52-54; G. E. Mendenhall, 'The Hebrew Conquest of Palestine', Biblical Archaeologist 25 (1962): 66-87; N. K. Gottwald, The Tribes of Yahweh: A Sociology of the Religion of Liberated Israel, 1250-1050 BCE (Sheffield: Sheffield Academic, 1999; repr. of first edn with new preface; first edn Maryknoll: Orbis, 1979).

14 See Dever, Early Israelites: 54.

15 R. B. Coote and K. W. Whitelam, The Emergence of Early Israel in Historical Perspective (Sheffield: Almond, 1987). 
Israel emerged. ${ }^{16}$ Thompson ${ }^{17}$ suggested that distinctive Israelite ethnicity cannot be traced in Palestine until the Persian era. The late Bronze-Early Iron transition is not related to ethnicity but is about socio-economic change and indigenous impulses. Especially, Thompson's reconstruction denies any historical reminiscences from the biblical text for the time before the exile and attempts to explain the origins of Israel completely independent from the biblical texts. ${ }^{18}$

On another thread of scholarship, a major archaeological work was published by Finkelstein on the Israelite settlement. ${ }^{19}$ In addition to making surveys of his own, he collated the results of archaeological excavations and surveys to form a picture about settlement patterns in the Israelite hill country, and the hill country of Ephraim in particular. Finkelstein showed conclusively that settlement increased substantially in the hill country of Ephraim in the Early Iron Age which he attributed to nomads who were resedenterising after having been forced to nomadic existence in the Late Bronze Age. ${ }^{20}$

Finkelstein's theory of resendenterising nomads has been criticised. ${ }^{21}$ For example, Dever ${ }^{22}$ suggests that the Israelites were rather a mixed group of less well-to-do people who went to the highlands in search of a better life. However, besides agreeing with Finkelstein that the settlement was essentially an indigenous

16 Coote and Whitelam, Emergence: esp. 117-38.

17 T. L. Thompson, Early History of the Israelite People: From the Written and Archaeological Sources (Studies in the History of the Ancient Near East, 4; Leiden: Brill, 1992).

18 For Thompson, the biblical text originates from the Persian period. On a wider scale, the works of Thompson, together with such scholars as Lemche and Davies, have raised a major controversy during recent years, as these scholars have suggested that nothing can be reconstructed about the history of Israel before the Babylonian exile based on biblical texts. However, this discussion does not concern us here except where it might touch the origins of Israel, especially as the assertions of these 'minimalist' scholars have in my view been adequately responded to by such works as W. G. Dever, What Did the Biblical Writers Know and When Did They Know It? What Archaeology Can Tell Us about the Reality of Ancient Israel (Grand Rapids, Michigan: Eerdmans, 2001) and V. P. Long, D. W. Baker and G. J. Wenham, ed., Windows into Old Testament History: Evidence, Argument, and the Crisis of 'Biblical Israel' (Grand Rapids, Michigan: Eerdmans, 2002).

19 Israel Finkelstein, The Archaeology of the Israelite Settlement (Jerusalem: Israel Exploration Society, 1988).

20 Archaeology: 336-51.

21 See P. McNutt, Reconstructing the Society of Ancient Israel (Library of Ancient Israel; Louisville, Kentucky: Westminster John Knox, 1999): 62 for a summary, and see Dever's fairly detailed critique in Early Israelites: 153-66.

22 Early Israelites: 181-82. 
development, Dever and many other scholars allow for the existence of a pastoral/nomadic element among the new immigrants..$^{23}$ It also can be noted that such scholars as Dever, Mendenhall and Gottwald allow for a small exodus group from Egypt as part of this settlement, even though these scholars have various views about the exact size and details of the group and its importance and impact in the process. ${ }^{24}$

Thus, we may summarise that while many scholars agree that the birth of Israel was largely an indigenous development, no further consensus has yet emerged. Against this backdrop, in the following, based on insights gleaned from studies of ethnicity and related intercultural studies, I will suggest a model which takes indigenous origins of Israel into account but also leaves room for the possibility of external origins as described in the biblical tradition. While adhering to the possibility of an external migration and conquest, the following presentation will not deny the well-known problems with the Exodus and conquest tradition, as already outlined above. However, space precludes their treatment in a short essay such as this. Therefore, I will leave the relevant problems mainly open, but will make some comments as appropriate during the course of what follows.

\section{Ethnicity and Old Testament Studies}

Recent years have seen a rise in interest in issues relating to ethnicity for Old Testament studies, even if the number of works devoted to the topic is small. ${ }^{25}$ As regards the Israelite settlement, a major issue has been whether an Israelite ethnicity can be distinguished on the basis of the archaeological record. While Finkelstein ${ }^{26}$ suggested that Israelite

23 See Dever, Early Israelites: 182; McNutt, Reconstructing: 62; T. E. Levy and A. F. C. Holl, 'Migrations, Ethnogenesis, and Settlement Dynamics: Israelites in Iron Age Canaan and Shuwa-Arabs in the Chad Basin', Journal of Anthropological Archaeology 21 (2002): 83-118; N. P. Lemche, The Israelites in History and Tradition (Library of Ancient Israel; Louisville, Kentucky: Westminster John Knox, 1998): 75-76. Cf. also Dever, Early Israelites: 143-51 for recent opinions of archaeologists.

24 See Dever, Early Israelites: 182; G. E. Mendenhall, Ancient Israel's Faith and History: An Introduction to the Bible in Context, ed. by Gary A. Herion (Louisville: Westminster John Knox, 2001); Gottwald, Tribes: 35-41.

25 E.g. Lemche, Israelites: esp. 65-85; K. L. Sparks (1998), Ethnicity and Identity in Ancient Israel: Prolegomena to the Study of Ethnic Sentiments and Their Expression in the Hebrew Bible (Winona Lake, Indiana: Eisenbrauns, 1998); M. G. Brett, ed., Ethnicity and the Bible (Leiden: Brill, 2002).

26 Archaeology: 29-32. 
ethnicity can be distinguished from material remains, such scholars as Edelman $^{27}$ and Lemche ${ }^{28}$ have denied this. On the other hand, recently Dever $^{29}$ has given good reasons which rather affirm that the archaeological record speaks for a distinct Israelite identity in Early Iron Age I. We will be looking at these issues more below. However, being focused on only those aspects of ethnicity which pertain to common culture, they are by no means the only issues that should be looked at. On the contrary, we shall be looking into wider definitions of ethnic identity and the possible and likely characteristics of this identity in early Iron Age Israel. While the discussion will refer to relevant archaeological evidence from early Iron Age Israel, its core will be based on studies of ethnicity which are completely outside the field of biblical studies and have hitherto been largely unexplored by biblical scholars. ${ }^{30}$ Part of the reason for this may be that ethnicity itself as a subject of study is quite recent. ${ }^{31}$

\section{Definitions and Basic Features of Ethnicity}

Let us start our cross-disciplinary investigation by looking at how people conceive ethnicity. First of all, while the terms of ethnicity, ethnic identity and ethnic group or community can be somewhat slippery and lack any agreed definition, ${ }^{32}$ we will follow here the well formulated, comprehensive and helpful definition given by John Hutchinson and Anthony Smith. ${ }^{33}$ According to Hutchinson and Smith, ethnic communities or ethnies ${ }^{34}$

habitually exhibit, albeit in varying degrees, six main features:

1) a common proper name, to identify and express the 'essence' of the community;

27 D. Edelman, 'Ethnicity and Early Israel' in Ethnicity and the Bible, ed. M. G. Brett (Leiden: Brill, 2002): 25-55.

28 Israelites: $65-85$.

29 Early Israelites: 191-200, esp. 193 table 11:1; 195 table 11:2.

30 Sparks, Ethnicity and Identity is a significant attempt in this direction, but nevertheless in my view ends up focusing more on issues relating to biblical criticism than on ethnicity.

31 See J. Hutchinson and A. D. Smith, ed., Ethnicity (Oxford Readers; Oxford: University Press): v.

32 See Hutchinson and Smith, Ethnicity: 4-7, including a short description of various approaches.

33 See Hutchinson and Smith, Ethnicity: 5-6 for the reasoning.

34 A term used by Hutchinson and Smith. 
2) a myth of common ancestry, a myth rather than a fact, a myth that includes the idea of a common origin in time and place, and that gives an ethnie a sense of fictive kinship, what Horowitz terms a 'super-family'; 3) shared historical memories, or better, shared memories of a common past or pasts, including heroes, events and their commemoration;

4) one or more elements of common culture, which need not be specified but normally include religion, customs, or language;

5) a link with a homeland, not necessarily its physical occupation by the ethnie, only its symbolic attachment to the ancestral land, as with diaspora peoples;

6) a sense of solidarity on the part of at least some sections of the ethnie's population ${ }^{35}$

As regards studies of ethnicity as a discipline, as Hutchinson and Smith $^{36}$ describe it, there are two basic approaches to ethnicity with their associated proponents, namely primordialism and instrumentalism. In addition to these, there are other approaches which play on further related issues. ${ }^{37}$ According to the primordial approach, ethnic ties are based on birth and other 'givens' and are seen as static and immutable. $^{38}$ On the other hand, according to the instrumental approach, ethnic ties are socially constructed and a function of circumstances and expediency. ${ }^{39}$ As Hutchinson and Smith $^{40}$ summarise, the primordial approach has been criticized for being overly static and naturalistic, whereas in reality ethnicity is more malleable, affected by the passage of time and change of historical and cultural circumstances. On the other hand, instrumentalists can be seen to look at matters only in terms of materialism and expediency which ignore the sense of permanence which people themselves have about their ethnic identity. ${ }^{41}$ However, it is also true that, as Hutchinson and Smith $^{42}$ point out, the approaches of scholars are often neither purely primordial or instrumental, but rather it is a matter of emphasis.

35 Hutchinson and Smith, Ethnicity: 6-7. Hutchinson and Smith refer to ch. 2 of the 1985 edition of D. Horowitz, Ethnic Groups in Conflict (Berkeley and Los Angeles: University of California, 2000; reprint of 1985 edition with a new preface) in relation to item 2 and to ch. 2 of Anthony D. Smith, The Ethnic Origins of Nations (Oxford: Blackwell, 1986) in relation to item 6.

36 Ethnicity: 8.

37 See Hutchinson and Smith, Ethnicity: 9-10 for summaries of the approaches of Barth ('transactionalist'), Horowitz ('social psychological'), and Armstrong ('ethnosymbolic').

38 Hutchinson and Smith, Ethnicity: 9.

39 Including material gains; Hutchinson and Smith, Ethnicity: 9.

40 Ethnicity: 9.

41 Hutchinson and Smith, Ethnicity: 9.

42 Ethnicity: 9. 
Related to the question of interplay between primordial ('static') and instrumental ('dynamic') aspects of ethnicity is the concept of ethnic boundaries and associated boundary markers. As $\mathrm{Nash}^{43}$ describes it, where there is a group, there has to be some way of distinguishing it from other groups. For ethnic groups, there are several 'index features' which serve this purpose. Nash ${ }^{44}$ adds that these boundary-marking features must be somehow recognisable both for members of the group and for outsiders. Boundary markers can include kinship, shared value systems, common language, style of clothing and similar physical features. ${ }^{45}$ It is the unique combination of such features for each ethnic group under specific circumstances which marks a boundary. ${ }^{46}$ On the other hand, differences in any such categories do not necessarily mean the existence of a boundary. ${ }^{47}$ Important here is also that there is individual variation as regards the strength of ethnic identities, ${ }^{48}$ and that members of an ethnic group may view boundaries differently than outsiders. ${ }^{49}$ Moreover, an individual can have multiple identities. For example, it is a well-known fact that an Asian immigrant to the United States who has changed their citizenship can view themselves as either belonging to their 'original' ethnic group in Asia, as Asian generally, or as American. ${ }^{50}$ Finally, the overall strength of boundary markers and the availability of opportunities to cross boundaries varies from one ethnic group to another, ${ }^{51}$ a point to which we shall return later.

43 M. Nash, 'The Core Elements of Ethnicity' in Ethnicity, ed. Hutchinson and Smith: 24-28, esp. p. 25, reproduced from The Cauldron of Ethnicity in the Modern World (Chicago and London: University of Chicago Press, 1989): 10-15.

44 Core Elements: 25.

45 Core Elements: 25.

46 E.g. Horowitz, Ethnic Groups: 41.

47 E.g. Horowitz, Ethnic Groups: 41-51; C. W. Stephan and W. G. Stephan, 'The Measurement of Racial and Ethnic Identity', International Journal of Intercultural Relations 24 (2000): 541-52; M. Weber, 'The Origins of Ethnic Groups' in Ethnicity, ed. Hutchinson and Smith: 35-40, esp. p. 38, repr. from 'Ethnic Groups' in Economy and Society, vol. 1, ed. G. Roth and C. Wittich (Berkeley and Los Angeles: University of California, 1978): 389-95.

48 Cf. C. Geertz, 'Primordial Ties' in Ethnicity, ed. Hutchinson and Smith: 40-45, esp. p. 42, repr. from 'The Integrative Revolution' in Old Societies and New States, ed. C. Geertz (New York: Free Press, 1963): 108-13.

49 E.g. Stephan and Stephan, Measurement; R. T. Halualani, 'Rethinking "Ethnicity" as a Structural-Cultural Project(s): Notes on the Interface between Cultural Studies and Intercultural Communication', International Journal of Intercultural Relations 24 (2000): 579-602.

50 Cf. Horowitz, Ethnic Groups: 65.

51 See Horowitz, Ethnic Groups: esp. 41-54. 


\section{Ethnicity and Ethnic Boundary Markers in Early Israel}

Having outlined a number of features of ethnicity above, let us see how they can be applied to the early Israelites. First of all, let us see what aspects of ethnicity would serve as possible identifiers of an ethnic group 'Israel' and as boundary markers between members belonging to Israel and members belonging to some other possible group during the Late Bronze-Iron Age transition and in the Early Iron Age. To do this, I will work on the basis of the definition given by Hutchinson and Smith as quoted above.

First of all, there is the question of a common name. The Bible itself is replete with expressions which distinguish the Israelites from other groups inhabiting the land. While the exact ethnic composition of Canaan during Late Bronze Age-Iron Age I is not clear, the Bible speaks about such groups as the Canaanites, Hittites, Amorites, Perizzites, Hivites and the Jebusites (e.g. Judg. 3:5). ${ }^{52}$ In addition, the Merneptah stela clearly indicates that there was an entity called Israel somewhere in the region of Canaan about $1200 \mathrm{BC},{ }^{53}$ and there is no doubt that an Egyptian, Assyrian and Hittite identity existed in a wider ancient Near Eastern context. ${ }^{54}$ Against this context, especially as the determinative for 'people' instead of region is used in the Merneptah stela, ${ }^{55}$ there are very good reasons to conclude that a group which was called Israel and was distinct in an ascriptive sense existed in Canaan during Late Bronze Age-Iron Age I. ${ }^{56}$

Secondly, the Bible is replete with descriptions of a belief in common ancestry for the Israelites. Stories that the Israelites are descendants of patriarchs Abraham, Isaac, Jacob and Joseph form a backbone of Israelite self-consciousness according to the Hebrew

52 Cf. Mendenhall, Faith and History: 11; J. G. McConville, Deuteronomy (Apollos Old Testament Commentaries; Leicester: Inter-Varsity, 2002: 152-53.

53 See esp. Hoffmeier, Israel in Egypt: 27-31; Dever, Early Israelites: 201-08; Sparks, Ethnicity and Identity: 94-109 for a description of some of the issues involved in the interpretation of the Merneptah stela. Overall, the archaeological record points to the hill country (see Finkelstein, Archaeology; Dever, Early Israelites: 201-08).

54 Cf. Sparks, Ethnicity and Identity: 23-93. For an analysis of the meaning of the determinative, see esp. Hoffmeier, Israel in Egypt: 27-31.

55 For the text, see K. A. Kitchen, Ramesside Inscriptions: Historical and Biographical, vol. 4 (Oxford: Blackwell, 1982): 12-19. According to Kitchen, it is very unlikely that the use of the determinative is a scribal error (personal communication, June 2004).

56 Cf. also Dever, Early Israelites: 216-21. 
scriptures. It is of course another matter how early such beliefs originated and when they were committed to writing. While there are scholars who would date the documents to the time before the monarchy, estimates for the time of writing generally vary from the early monarchy to the Persian period, in line with various views of the dating of the Old Testament documents. ${ }^{57}$ Therefore, for the sake of our argument here, we cannot be certain whether such beliefs existed during the time of the early Israelites. However, undoubtedly this is a viable possibility. If so, it is likely that they were different from those of the surrounding peoples and distinguished the Israelites from these peoples. We shall return to this point later. However, at this point we also note that it is difficult to say whether the people in the Levantine area exhibited major phenotypal (i.e. relating to physical outlook) differences. The ancient Near Eastern and biblical documents seem to provide no evidence that this was the case, at least on any significant scale. Therefore, it is less likely that an Israelite would have distinguished himself or herself from people of the other groups on the basis of phenotypal differences.

Thirdly, and closely related to the previous point, the Bible is full of historical memories of a common past. The stories about the patriarchs and the Egyptian sojourn and slavery and the subsequent Exodus provide a foundation for a shared history. As already indicated above and as is well known, the origin and historicity of these stories is much disputed, but again, there is the possibility that a group of slaves had escaped from Egypt and entered the land of Canaan during the time of the early Israelites, whatever the historical circumstances surrounding them might be as opposed to what the biblical sources attest. ${ }^{58}$ These people might also have had at least some kind of historical reminiscences about the patriarchs. It would be very possible that the combination of historical memories about the patriarchs and the Exodus would distinguish the adherents of this group from other people in Canaan.

57 See G. J. Wenham, 'Pondering the Pentateuch: the Search for a New Paradigm' in The Face of Old Testament Studies: A Survey of Contemporary Approaches, ed. D. W. Baker and B. T. Arnold (Grand Rapids: Baker, 1999): 116-44 for a survey of recent approaches. See also P. Pitkänen, Central Sanctuary and Centralization of Worship in Ancient Israel: from the Settlement to the Building of Solomon's Temple (Piscataway, New Jersey: Gorgias, 2003) for a number of issues which relate to dating Old Testament documents.

58 Cf. above, p. 165; see also Hoffmeier, Israel in Egypt. 
Fourthly, there is the question of a common culture. In relation to this, it is unlikely that language, which is always intertwined with culture, is an issue as Hebrew is a Semitic language and is likely to have had mainly dialectal differences with other languages in the area. ${ }^{59}$ As regards religion, the Bible of course clearly distinguishes Yahwism from the surrounding religions. However, the origins of Yahwism are debated. ${ }^{60} \mathrm{In}$ a broad sense, these fall along the lines of other views of Israelite origins. If the Israelites originated from the Canaanites indigenously, then it is likely that the origin of Yahwism lies in Canaanite religion. On the other hand, if at least some of the Israelites came from outside, bringing a belief in YHWH with them, it is possible to see Yahwism as a development more or less external to Canaan. It must also be kept in mind that there may have been a big gap between the Yahwism advocated by the canonical documents and that of popular religion. The biblical documents themselves clearly indicate that this was the case, and archaeological evidence from the time of the monarchy confirms cases where YHWH was put on a par with another deity. ${ }^{61}$ Whatever the complications, for the sake of our argument, there is nevertheless a possibility that some of the early Israelites believed in a deity called YHWH. How widespread this belief may have been and whether, when and how much it distinguished an Israelite from surrounding peoples in practice is a matter about which we cannot be certain.

Continuing with aspects of common culture, there have been attempts to determine whether any external aspects of Israelite culture can be detected from the archaeological record. As mentioned above, the debate probably started with Finkelstein ${ }^{62}$ who suggested that Israelite ethnicity can be distinguished from material remains. However, such scholars as Edelman ${ }^{63}$ and Lemche ${ }^{64}$ have denied this,

59 Cf. the Sibboleth incident in Judg. 12:1-6 which indicates dialectal differences even within different regions in Israel.

60 For a summary, see R. Gnuse, 'The Emergence of Monotheism in Ancient Israel: A Survey of Recent Scholarship', Religion 29 (1999): 315-36.

61 E.g. 'Yahweh and his Asherah' from Kuntillet Ajrud; A. Mazar, Archaeology and the Land of the Bible 10,000-586 BCE (Anchor Bible Library; New York: Doubleday, 1990): 446-50. Cf. J. S. Holladay, 'Religion in Israel and Judah Under the Monarchy: An Explicitly Archaeological Approach' in Ancient Israelite Religion: Essays in honor of Frank Moore Cross, ed. P. D. Miller, Jr., P. D. Hanson, S. D. McBride (Philadelphia: Fortress, 1987): 249-99; Gnuse, Emergence.

62 Archaeology: 29-32.

63 Ethnicity. 
undoubtedly in line with their general tendency to see the development of Israelite identity as a later phenomenon. Yet, recently Dever ${ }^{65}$ has given good reasons which rather affirm that the archaeological record speaks for a distinct Israelite identity in Early Iron Age I. In addition, Dever ${ }^{66}$ suggests that the archaeological record speaks for the birth of a new identity. Dever's observations merit further attention. First of all, there is an increase in rural settlement, with a population explosion most notably in the hill country. Accompanying site and house layouts indicate an emphasis on extended family and clan. Moreover, the archaeological record speaks for an agrarian mode of production and communitarian and tribal organisation. ${ }^{67}$ On the other hand, according to Dever, ${ }^{68}$ there is continuity in technology, and in art, religion and language. While all the new features could be interpreted as simply an indication of increase in rural settlements, a comparison of the situation during Iron Age I and II suggests otherwise. Most notably, during Iron Age II, settlement becomes more urban and centralized, population expands, systems and public works expand, settlement layouts indicate a more stratified society with a more uneven wealth distribution. ${ }^{69}$

Thus, the cumulative evidence is suggestive. Some kind of new unit was born in the highlands, distinctive from what was before and after it, and distinctive from what was around it in the lowlands. In addition, it is striking that the picture that the archaeological record gives is basically in line with the biblical descriptions of premonarchical society, especially as portrayed in the book of Judges. ${ }^{70}$ While many of the features we have outlined above can be seen in economic terms, even if an egalitarian society may have been a product of circumstances, it would be likely that such a society would leave its marks on the consciousness of the people who live in it and be a distinguishing feature as against societies in the lowlands. We should also point out one small but significant potential boundary marker.

\footnotetext{
64 Esp. Israelites: 65-85.

65 Early Israelites: 191-200, esp. 193 table 11:1; also 195 table 11:2.

66 Early Israelites: 191-200.

67 Summarised in Dever, Early Israelites: 193 table 11:1.

68 Early Israelites: 193.

69 Dever, Early Israelites: 195-200.

70 So also Dever, Early Israelites: 228, according to whom the stories of Judges 'of a two-century sociological and religious struggle against the prevailing local Canaanite culture fits astonishingly well with the current archaeological facts on the ground'.
} 
Pork bones are almost entirely absent from the Iron I highlands, in contrast to the lowlands. ${ }^{71}$

We still have one important aspect of common culture to consider, namely, circumcision. According to the biblical tradition, circumcision was a boundary marker (Gen. 17; 1 Sam. 31:4). However, one may not assume that all people around Israel were uncircumcised, and the biblical tradition itself seems to hint that not all Israelites were necessarily circumcised in actuality (Josh. 5:1-9). ${ }^{72}$ The usual reservations about the origin and date of the circumcision tradition also apply, and circumcision is pretty much undetectable based on material remains. Therefore, circumcision may have been a boundary marker in early Israel, but if so, it is difficult to say to what extent. ${ }^{73}$

Coming to the fifth point of the main features of ethnies according to Hutchinson and Smith, a link with a homeland, the land of Canaan features as a particularly strong concept in the biblical tradition. Certainly this is the case with the Babylonian exiles, but by no means exclusively so. ${ }^{74}$ Examples throughout history also indicate that people who have been displaced from their country of birth often long to be back there. ${ }^{75}$ From the standpoint of ethnicity, it would not be likely that land would be a distinguishing feature between the early Israelites and non-Israelites, as both would be essentially living in the same area, albeit perhaps with the distinction between the highlands and the lowlands.

Finally, we come to the sixth of Hutchinson and Smith's points, a sense of solidarity among at least part of the people constituting the ethnie. This point is very much linked to all the previous points. And, according to the Old Testament, such a solidarity existed during the premonarchical period. In particular, leaving aside the books of Exodus-Joshua, according to the books of Judges and Samuel the Israelites could assemble together if threatened. ${ }^{76}$ As we basically only have the biblical text to support this view, for the sake of argument, we

71 E.g. Dever, Early Israelites: 108.

72 Cf. P. J. King and L. E. Stager, Life in Biblical Israel (Library of Ancient Israel; Louisville, Kentucky: Westminster John Knox, 2001): 43-45.

73 One would also have to ask how much circumcision would have been linked to Yahwism, especially in the minds of ordinary people.

74 See the usual documents relating to the patriarchs, the Exodus and the conquest.

75 Cf. also the story of Sinuhe from Egypt.

76 See e.g. Judg. 3-4 (Deborah) and other judges; Judg. 19-21 (the crime of the men of Gibeah); 1 Sam. 11 (Saul and the Ammonites). 
note it only as a possibility at this stage. Such a solidarity would of course be an indicative feature distinguishing those who belong to Israel from those who do not.

In summary, we find that one can think about possible distinctive Israelite identity and the existence of ethnic boundaries during Late Bronze Age-Iron Age I. Minimal possible boundaries on which we have reasonable evidence would be being called an Israelite, believing in descent from the patriarchs or the like, believing in a common history of the patriarchs and an Egyptian sojourn and exodus, having an egalitarian ideology, believing in some food restrictions, such as abstaining from eating pork, believing in the practice of circumcision, and having some sense of obligation towards fellow Israelites. It is difficult to say to what extent belief in YHWH could have been a boundary marker, especially across the population as a whole, but it may have been one at least in some sense. Perhaps more boundary markers could be thought of on the basis of common culture, but the ones outlined above, most of which are archaeologically undetectable and yet completely plausible, seem to be potentially the most conspicuous and important.

\section{Assimilation in Early Israel}

Having outlined possible ethnic identifiers and boundary markers in early Israel, I now propose that we could devise a situation where a group of slaves who have escaped from Egypt takes a foothold in the less inhabited highland 'frontier' 77 and starts to settle there. The Exodus group brings with it a belief in common ancestry from the patriarchs and stories about them and about the exodus. Due to escape from slavery, the group also has an egalitarian ideology. The group brings with it a belief in YHWH and includes members fanatically committed to Yahwism. The members of the group also believe in circumcision and in food restrictions, such as a restriction on eating pork. The group calls itself Israel in line with the name of its common ancestor Israel according to its beliefs.

While the Exodus group settles, individual Canaanites join the group and adopt Israelite customs, become grafted into Israelite

77 For this term, see Dever, Early Israelites: 180-81; Finkelstein, Archaeology: 33839. 
genealogies and adopt Israelite beliefs of common ancestry and history. Also, through conquest or voluntarily, some highland cities are similarly assimilated to Israel, though other cities stay independent. This process continues through centuries, expanding beyond the highlands during the early monarchy. Thus, Israel is born in Egypt and grows in and from Canaan. Let us next look at the evidence in support of this, in the light of our discussion so far and based on cases of assimilation elsewhere.

Let us start from the well-known fact that the biblical tradition is ostensibly against the Canaanites (Joshua, Judges, etc.). There is to be no intermarriage or mixing with them. No covenants or treaties with them are to be made. The Canaanites are simply to be destroyed. Any casual reader of the Bible will notice the strong rhetoric for this.

However, if one reads more carefully, the biblical tradition also indicates that non-Israelites can be incorporated into Israel. Caleb is the son of Jephunneh the Kenizzite, and yet Caleb belongs to the tribe of Judah (e.g. Num. 13:6). In other words, while Caleb's background is Kenizzite, he has been grafted into the tribe of Judah, having a dual ethnicity. Another example is the 'mixed multitude' which left with Israel from Egypt (Exod. 12:38 etc.). If it reflects an actual historical remembrance, these people must have been included in Israel, and somehow in the Israelite tribal system, assuming that the tribal system may have originated early. ${ }^{78}$

Deuteronomy 23:1-8 provides another interesting example. According to the passage, no Ammonite or Moabite may enter the assembly of the Lord, even to the tenth generation (v. 3). ${ }^{79}$ However, children of Edomite or Egyptian descent may enter the assembly in the third generation (vv. 7-8). Whatever the date of the passage, ${ }^{80}$ entering the assembly of the Lord presumably suggests that these people have at the least moved away from being excluded from Israel. ${ }^{81}$

78 This is of course disputed, in accordance with the question of when the Israelite identity emerged. See also G. W. Ahlström, The History of Ancient Palestine (Minneapolis: Fortress, 1993): 278 for the possibility that the name Asher may have originated early.

79 Note however that Ruth, the ancestress of David, was a Moabitess (Ruth 1:4). Note also that even if the origin of the Deuteronomic legislation is taken to be late, often the book of Ruth is seen as even later than Deuteronomy.

80 For a number of issues which relate to dating Deuteronomy, see Pitkänen, Central Sanctuary.

81 Cf. McConville, Deuteronomy: 350 who suggests assimilation. 
The above examples concern people who originate from outside the territory of Canaan. However, we have the example of Rahab in the book of Joshua where an inhabitant of Canaan is taken into the Israelite community. While the exact nature of Rahab's status is unclear, according to the biblical tradition, she lived among the Israelites after the conquest of Jericho (Josh. 6:25). Rahab, as well as Ruth, the ancestress of David may have been considered Israelite as well as keeping her original ethnic identity.

We now move to further examples. Numbers 27 and 36, and Joshua 17:3-6, describe the case of the daughters of Zelophedad. These women are told that they can possess the inheritance of their fathers in the absence of male heirs, but are to marry with men in their own tribe so that the inheritance stays within that tribe. The intriguing point with this story is that a number of the names of the daughters are the same as districts in the area of Manasseh mentioned in the Samaria ostraca. Tirzah is also mentioned in the book of Joshua as a city state conquered by Israel (Josh. 12:24). ${ }^{82}$ In addition, in Numbers 26:31 Shechem, a name which coincides with the well-known already existing Canaanite city, is listed as a son of Gilead which itself coincides with the name of a geographical area in Transjordan. Similarly, Hepher, the father of the daughters of Zelophedad, is listed as a city in Joshua 12:17 and Numbers 26:32. All these cities are also within the territory of Manasseh, in the hill country which the Israelites are likely to have controlled early ${ }^{83}$ It is unlikely that this is all coincidence. Rather, the names reflect that these areas became part of Israel. In this respect, while I agree with Milgrom' ${ }^{84}$ suggestion that assimilation of the areas in question is likely to be implied, rather than treating them as pure eponyms as Milgrom does, I suggest that the names reflect the allotment and early settlement of these areas. Specifically, for example, it is conceivable that the daughters of Zelophedad were given areas referred to in Numbers $26: 33$ as an inheritance. The areas themselves became part of Israel, but the original names of the daughters were lost

82 See J. Milgrom, Numbers (JPS Torah Commentary; Philadelphia and New York: Jewish Publication Society, 1989): 224.

83 See Milgrom, Numbers: 224, including the suggestion that the list in Num. 26 has an early date; cf. M. Noth, Das System der zwölf Stämme Israels (Stuttgart: Kohlhammer, 1930): 129; Pitkänen, Central Sanctuary: 232 n. 565.

84 Numbers: 224. 
from the tradition and replaced by the names of the localities. ${ }^{85}$ If so, it would mean that one family would have received a considerably large area to settle, which in itself would beg the question of how it could populate and take care of such an area by itself. Rather, one would suspect that more might be involved, and a contribution from a local population would fit the scene.

In addition, while the conquest of the leader (mélékh) of Tirzah is mentioned in Joshua 12:24, no information is given as regards the conquest of the other localities mentioned above, including Shechem. Moreover, the tradition of Joshua 12:24 only says that the king (mélékh) of Tirzah was conquered, but nothing is said about the city itself. We may add Jerusalem to our considerations here. While Joshua 12:10 and Judges 1:8 suggest that the king of Jerusalem was defeated and the city captured, elsewhere the biblical tradition states that the city remained independent and was incorporated into Israel only at the time of David (see Josh. 15:63; Judg. 1:21; 19:10-12; 2 Sam. 5:6-10; 1 Chr. 11:4-8). In addition, nothing is said about what happened to the inhabitants of Jerusalem after David captured it. Thus, overall, even if the tradition about the capturing of the cities is correct, it is by no means certain that all of the inhabitants were slaughtered in every case. In addition, the book of Joshua which portrays a victorious Israel may well include hyperbolaic language when speaking about the conquest of cities and areas, in line with other contemporary ancient Near Eastern documents. ${ }^{86}$

Thus, we note that it is by no means certain what happened to a number of the cities and areas and their inhabitants which Israel took under its control according to the biblical tradition, especially in the northern highlands where Israel can be thought to have emerged first. It may be that Israel simply had overall control of the areas and cities but could or did not necessarily kill their inhabitants. In other words, one could imagine that some of the people who were left in the land actually became Israelites. Certainly, this would be in accord with the

85 Note that while the daughters of Zelophedad are females, Shechem is a male. Note also that that the names of the localities were part of an early tradition would rather reflect that these areas became part of Israel at an early stage.

86 See K. L. Younger, Ancient Conquest Accounts: A Study in Ancient Near Eastern and Biblical History Writing (JSOTSup, 98; Sheffield: Sheffield Academic, 1990). Mendenhall, Hebrew Conquest also mentions the possible changing of hands of cities; cf. e.g. $2 \mathrm{Kgs}$ 13:25. 
biblical notion of intermarriage which took place between the Israelites and the local inhabitants of the land (Judg. 3:6).

Moving into ethnic studies at this point, Horowitz ${ }^{87}$ shows examples of how people from one ethnic group can be assimilated into another. Assimilation takes place by changing one's identity. As Horowitz ${ }^{88}$ describes, 'When it becomes useful, particularly in order to absorb successful or potentially troublesome members of ranked subordinate groups, superior groups may conveniently 'forget' the origins of individuals or families' ${ }^{89}$ Horowitz states in particular the example of Tutsis and Hutus in Rwanda. According to Horowitz,

In the ranked system of eastern Rwanda, for example, Tutsi were superordinate and Hutu subordinate. 'Yet, the evidence shows that in some cases the strength of the local Hutu lineages was such that the Tutsi found it expedient to absorb these meddlesome "upstarts" into their own caste. In a fascinating discussion of the power struggle which took place in Remera, Gravel notes that "the Hutu lineages which have been in situ longest have acquired some sort of priority of rights on the hill. Their members are respected and the heads of the lineages have much influence on their neighbours, and have an important voice in local administration ... The powerful lineages keep the power of the [Tutsi] chieftain in check. If, however, they become powerful enough to threaten the chieftainship they are absorbed into the upper caste. Their Hutu origins are "forgotten". 90

The above example, together with the evidence we have gathered so far, is suggestive for early Israel. If the tradition that the Israelites got control of the highlands is correct, and that they subjugated the local inhabitants there but did not destroy all of them, it is likely that the remaining Canaanites were at first subordinate (cf. Judg. 1:28), but became part of Israelite society in the course of time..$^{91}$ In other words,

87 Ethnic Groups.

88 Ethnic Groups: 48.

89 For Horowitz, two groups are ranked if relationships between them 'entail clearly understood conceptions of superordinate and subordinate status' (Ethnic Groups: 22). On the other hand, 'in unranked systems, parallel ethnic groups coexist, each group internally stratified' (p. 23).

90 Horowitz, Ethnic Groups: 48 n. 146, quoting R. Lemarchand, 'Power and Stratification in Rwanda: A Reconsideration', Cahiers d'Etudes africaines 6 (Dec 1966): 604-05, who quotes P. Gravel, The Play for Power: Description of a Community in Eastern Rwanda (Ph.D. dissertation, 1962).

91 Note also the Gibeonites (Josh. 9; 2 Sam. 21), a 'middleman minority' according to Josh. 9:27 who remained distinct for a long time as a group. For a definition of a middleman minority, see D. Levinson, Ethnic Relations: A Cross-Cultural Encyclopedia (Santa Barbara, California: ABC-CLIO, 1994): 148-49. However, middlemen minorities often assimilate into the mainstream (Levinson, Ethnic Relations: 149), and 
in the course of time, individuals and families, and perhaps even whole communities, ${ }^{92}$ would become Israelites and be grafted to the Israelite lineage. In this respect, without doubt, it would be most natural to think that the new entrants would be grafted into the tribe in whose territory they were living. A number of these new members could also be from any of the cities or areas not under Israelite control who would migrate to the highlands in search of a better life. ${ }^{93}$

With the change of identity, the new entrants, setting aside their original background, would also be likely to adopt Israelite foundation stories. ${ }^{94}$ The fact that the patriarchal stories take place in Canaan would no doubt make it easier to associate with them, even if the stories also speak about the sojourn and exodus from Egypt. Moreover, the new entrants would adopt an egalitarian ideology like the Israelites. While the justification for this ideology would ostensibly be liberation from Egypt, it would fit the conditions of the highland frontier where everyone needed to cooperate in order to survive. ${ }^{95}$ Any oppressed people looking for a better life at the highland frontier would undoubtedly associate with such an ideology. ${ }^{96}$ The frontier would help facilitate the acceptance of a common Israelite solidarity for the new entrants.

The new entrants would also adopt Israelite customs. In particular, restrictions on pork consumption would be enforced by Israelites and adopted by the new entrants, and circumcision might start being practised, even if no archaeological evidence exists to confirm or deny this.

Thus, all of the minimal boundary markers of being called an Israelite, believing in a descent from the patriarchs or the like, believing in a common history of the patriarchs and in an Egyptian

therefore it is entirely possible that at least individual members of Gibeonites could have assimilated to Israel from early on.

92 Cf. Horowitz, Ethnic Groups: esp. 64-65 re Gen. 34:13-24.

93 Cf. Dever, Early Israelites. Cf also Horowitz, Ethnic Groups: 78 which gives an African example where Mossi migrants from Upper Volta to Kumasi, Ghana create fictive family relationships with other Mossi which helps them to become part of the community in Kumasi. Note further the regulations concerning gér and toshav in the Old Testament, whatever their origin as such. It would be logical to think that over the course of time a gér or toshav and/or their descendants could end up assimilating. Note also how the frontier served as a melting pot especially for Europeans when the United States was formed.

94 An immigrant to the modern US would be likely to adopt American foundation stories, or at least his or her children would, as part of growing up in the society.

95 Cf. Dever, Early Israelites: 185.

96 Cf. Gottwald, Tribes. 
sojourn and exodus, having an egalitarian ideology, accepting some food restrictions, such as abstaining from eating pork, the practice of circumcision, and having some sense of obligation towards fellow Israelites would have been crossed by the new entrants (cf. above). Some of the assimilating individuals and groups may even have embraced Yahwism, whatever form of Yahwism it might have been. ${ }^{97}$

We may however ask, how easy would it then have been to cross the ethnic boundary in order to become an Israelite? As Horowitz ${ }^{98}$ notes, the strength of ethnic boundaries varies case by case. It is often difficult to predict the ease by which boundaries can be crossed, but as common origin and therefore familial ties are an important part of belonging to an ethnic group, the ease with which marriage outside the group can take place is one indicator of the strength of the sense of ethnic identity. ${ }^{99}$ As Horowitz ${ }^{100}$ notes, 'rates of exogamy for severely divided societies typically run below 10 percent of all marriages, and probably lower if only unions between the most-conflicted groups are counted'. On the other hand, 'societies with more moderate levels of ethnic conflict generally have somewhat higher rates of exogamy'. ${ }^{101}$ We may compare these comments with the biblical evidence. The Deuteronomic literature precisely tries to limit intermarriage as part of avoiding contact and mixing with the local population. On the other hand, such passages as Judges 3:6 state that there was intermarriage between Israelites and the local population and therefore suggest that in actual practice, the polarisation between these two groups was rather less severe. ${ }^{102}$ In fact, there are extra-biblical examples where, despite strong ideological exclusiveness within a group, members from another group are assimilated. ${ }^{103}$ In other words, the biblical evidence suggests that there was intermixing. This then speaks for the assimilation of local population. We may also note that we are given a picture of an ethnic identity for early Israelites which is a mixture of primordial and functional elements. The identity is primordial in the sense that there is

97 Cf. Horowitz, Ethnic Groups: 50 about changing one's religion as part of one's ethnic identity.

98 Ethnic Groups: 55-56.

99 Horowitz, Ethnic Groups: 61.

100 Ethnic Groups: 62, with examples.

101 Horowitz, Ethnic Groups: 62, with examples.

102 It can also be added that the biblical evidence clearly suggests that the Israelites mixed religiously with the Canaanites.

103 See Crüsemann 2002: 63, n. 22. 
a belief in the ancestors and 'founding fathers' and an associated history, but functional in the sense that Canaanite elements adopt it. Thus, we may say that according to this model, Israel originates in Egypt but grows in and from Canaan. The process begins with the entry of the Egyptian slaves into Canaan and continues for a number of centuries, well into the period of the monarchy. ${ }^{104}$

We may further ask, how many Canaanites would have been assimilated? Based on recent studies which emphasise the indigenous origins of Israel, there pretty much seems to be no upper limit. On the other hand, is there a lower limit? This question would be tied to the question of the possibility of the entry of an external group into the Israelite hill country in the first place. Naturally, we have the problems with the Israelite conquest stories, including the well known archaeology related problems with Exodus-Joshua, with such sites as Jericho and Ai a case in point. ${ }^{105}$ It is not the purpose of this article to solve these problems, but if they are somehow solvable, our considerations above would fit well with an external group entering the area and obtaining control over the highlands, at the same time assimilating local inhabitants to form a new entity called Israel. In any case, the population increase in the highlands could easily be attributed conceptually to an increase from outside, at least in part. ${ }^{106}$

\section{Conclusion}

In summary, based on comparative studies of ethnicity, we have suggested the possibility that a group from Egypt gained a foothold in

${ }^{104}$ Cf. 1 Kgs 9:20-21, but cf. Ezra 2:55-58 where these elements seem to have been assimilated.

$105 \mathrm{Cf}$. above. Note however for example that the existence of pottery in the tombs of Jericho during late Bronze Age is suggestive that the area may not have been quite as abandoned as is often suggested.

106 Dever, Early Israelites: 121 claims that the continuity of LB Canaanite and IA Israelite pottery argues against an influx of outsiders. According to Dever (p. 121), it would be inconceivable that an outside group would not bring its own pottery traditions with them, but would instead adopt the local pottery repertoire and replicate it exactly. However, the biblical tradition emphasizes that the Israelites adopt the overall Canaanite material culture (Deut. 6:10-11). Also, elsewhere Dever himself points out that the hill country attests a lack of refined art and aesthetics (p. 126). This seems a logical inconsistency as one would rather expect based on the argument from pottery that immigrants from the lowlands (who are included in the early Israelites according to Dever) would be expected to bring artistic traditions with them! In addition, Dever (Early Israelites: 121) acknowledges that the use of pottery has to do with functional and situational aspects. 
the Canaanite highlands, and assimilated and amalgamated local people(s) over the course of ensuing centuries. In this way, Israel came to exist. Such a model would be reasonably in accord with the biblical data, archaeological evidence from the Israelite hill country, and the main contours of ethnic studies. The model is in a number of ways similar to recent theories which stress indigenous origins of Israel. However, it is different in that it interprets matters from the standpoint of the foundational importance of the Egypt group and its success in taking foothold in the highlands and in incorporating the resident population into an amalgamation in which its origin and foundation stories, and finally Yahwistic religion, became paramount. ${ }^{107}$

107 See also the following works, used in the writing of this article but not directly cited: F. Barth, 'Ethnic Groups and Boundaries' in Ethnicity, ed. Hutchinson and Smith: 40-45, repr. from F. Barth, Ethnic Groups and Boundaries (Boston: Little, Brown and Co., 1969): 10-19; C. A. Crocker, 'How to Think about Ethnic Conflict', Orbis 43, 4 (1999): 613-20; F. Crüsemann, 'Human Solidarity and Ethnic Identity: Israel's Self-definition in the Genealogical System of Genesis' in Ethnicity, ed. M. G. Brett: 57-76; O. I. Davis, T. K. Nakayama and J. N. Martin, 'Current and Future Directions in Ethnicity and Methodology', International Journal of Intercultural Relations 24 (2000): 525-39; J. H. Drell, 'Cultural Syncretism and Ethnic Identity: The Norman "Conquest" of Southern Italy and Sicily', Journal of Medieval History 25, 3 (1999): 187-202; I. Finkelstein and N. Naaman, ed., From Nomadism to Monarchy: Archaeological and Historical Aspects of Early Israel (Jerusalem: Israel Exploration Society, 1994); I. Finkelstein and N. A. Silberman (2001), The Bible Unearthed: Archaeology's New Vision of Ancient Israel and the Origin of Its Sacred Texts (New York: Simon \& Schuster); S. E. Grosby, Biblical Ideas of Nationality: Ancient and Modern (Winona Lake, Indiana: Eisenbrauns, 2002); W. W. Isajiv, 'Approaches to Ethnic Conflict Resolution: paradigms and principles', International Journal of Intercultural Relations 24 (2000): 105-24; J. A. Knudtzon (1964/1915), Die ElAmarna Tafeln: Mit Einleitung und Erläuterungen, 2 vols (Aalen: Otto Zeller Varlagsbuchhandlung; repr. of 1915 edn); J. Kurth, 'Religion and Ethnic Conflict - In Theory', Orbis 45, 2 (2001): 281-94; L. M. Osbeck, F. M. Moghaddam and S. Perreault, 'Similarity and Attraction among Majority and Minority Groups in a Multicultural Context', International Journal of Intercultural Relations 21:1 (1997): 113-23; U. Piontkowski, A. Florack, P. Hoelker and P. Obdrzalek, 'Predicting Acculturation Attitudes of Dominant and Non-Dominant Groups', International Journal of Intercultural Relations 24 (2000): 1-26; Pritchard 1993: 511-14; F. Psalidas-Perlmutter, 'Ethnic Conflicts: The Interplay of Myths and Realities', Orbis 44, 2 (2000): 237-44; J. Rex and D. Mason, ed., Theories of Race and Ethnic Relations (Comparative Race and Ethnic Relations Series; CUP 1986); J. Spencer-Rodgers and T. McGovern, 'Attitudes toward the Culturally Different: The Role of Intercultural Communication Barriers, Affective Responses, Consensual Stereotypes, and Perceived Threat', International Journal of Intercultural Relations 26 (2002): 609-31; I. W. Zartman, 'Ethnic Conflicts: Mediating Conflicts of Need, Greed and Creed', Orbis 44:2 (2000): 255-66. 